\title{
ROLE OF ORGANISMS OF THE PLEUROPNEUMONIA GROUP IN HUMAN GENITAL INFECTIONS * $†$
}

\author{
BY \\ C. S. NICOL and D. G. ff. EDWARD \\ St. Bartholomew's Hospital and the London Hospital, London, \\ and the Wellcome Research Laboratories, Beckenham, Kent
}

The isolation of organisms of the pleuropneumonia group from the human genital tract has aroused considerable interest in view of the attention now being paid to the aetiology of non-specific (non-gonococcal) urethritis. The first isolation of a pleuropneumonia-like organism from man was made by Dienes and Edsall (1937) from a Bartholin's abscess. Dienes and his associates (Dienes, 1940 ; - Dienes and Smith, 1942 ; Dienes and others, 1948) later showed that organisms of the pleuropneumonia group were frequent inhabitants of both male and female genital tracts, and suggested that these organisms might cause infection. Beveridge, Campbell, and Lind (1946) isolated pleuropneumonia-like organisms from the urethra of 20 per cent. of men with non-specific urethritis ; urethral cultures from healthy men were negative. Harkness and Henderson-Begg (1948) obtained similar results, so that it appeared possible that pleuropneumonialike organisms might cause non-specific urethritis. More recently, however, pleuropneumonia-like organisms were found in urethral cultures from 10-16 per cent. of men without evidence of infection (Harkness, 1950; Melén and Linnross, 1952). Positive isolations from the female were even more frequent ; in one series of 300 cervical cultures, 26 per cent. were positive (Randall, Stein, and Ayres, 1950). The organisms were found more frequently in women with genital infection than in those with no evidence of infection; cultures from a small number of virgins were negative (Melén and Odeblad, 1952).

The significance of organisms of the pleuropneumonia group in genital infection was discussed by Edward (1952), who did not consider that the evidence was sufficient for conclusions to be drawn. Although the organisms had sometimes been

* Received for publication July 10, 1953.

† Paper read before the M.S.S.V.D. April 24, 1953. isolated in pure culture from suppurative lesions, the frequency with which they were found in the vagina and their isolation from the urethra of healthy men suggested that they might be part of the normal flora. It was, however, possible that the organisms isolated from patients with infection belonged to a different species of the pleuropneumonia group from those isolated from healthy persons. Pleuropneumonia-like organisms belonging to at least three different species have been isolated from the vagina of bitches (Edward and Fitzgerald, 1951a). Few attempts have been made to find out whether the pleuropneumonia-like organisms isolated from the human genital tract belong to more than one species. In the investigations to be reported cultures from both infected and healthy persons were examined and the strains of pleuropneumonia-like organisms isolated were compared by biological and serological methods to find out whether any particular species or type of organism was associated with disease.

\section{Material and Methods}

The investigation was carried out on 468 patients ; 336 of them, including ninety police candidates examined as controls, were seen at the Special Treatment Centre at St. Bartholomew's Hospital, and 132 at the Whitechapel Clinic of the London Hospital. All patients had smears and cultures to exclude gonococcal infection and an examination for Trichomonas vaginalis was made by the moist-slide method. Routine serological tests (W.R., Kahn, and G.C.F.T.) were also made.

Altogether 1,155 cultures were examined for organisms of the pleuropneumonia group. Specimens were collected using sterile cotton wool swabs, which were afterwards placed in 2-ml. amounts of a horse serum broth medium in screw-cap bottles. Early in the investigation the male urethra was irrigated with the broth medium, but this practice was discontinued after a patient developed an allergic reaction at the third time of testing. The swab method appeared to give as many positive cultures as 
the instillation method. In the female, specimens were taken from the cervix without first removing any vaginal discharge; thus the swab collected both cervical and vaginal secretions.

The broth samples were usually cultured within a few hours, but could be stored satisfactorily at $-20^{\circ} \mathrm{C}$.; pleuropneumonia-like organisms were isolated from samples even after storage for several months at this temperature. The broth samples were inoculated directly, without preliminary incubation, on to special media, made from ox heart infusion broth containing 1 per cent. added peptone with the further addition of 10 per cent. yeast extract and 20 per cent. horse serum, the $p H$ being adjusted to 8.0. Both a solid medium and a semi-solid medium were employed. Thallium acetate and penicillin were added as bacteriostatics to provide a selective medium (Edward, 1947) ; only on a few occasions were cultures overgrown by bacteria. Penicillin was only applied to half of the surface of a plate. When colonies of pleuropneumonia-like organisms were present, they appeared on both halves of the plate, unless the penicillinfree half was overgrown with bacteria. There was therefore no suggestion that bacteria were induced by the penicillin to form L-phase variants, which were mistaken for organisms of the pleuropneumonia group.

The plates were examined with a dissecting microscope using slightly oblique transmitted light; this is considered to be the easiest and most reliable method for identifying an organism of the pleuropneumonia group (Edward, 1953). From every positive culture a subculture was made from a single colony; each of the strains thus isolated was examined to determine its biological and serological properties. The type of growth in a semi-solid medium was noted. Cultures on horse serum agar were examined for the formation of a film and spots. The ability to grow on rabbit serum agar, the ability to ferment glucose, and the ability to produce haemolysis of horse blood agar were also tested (Edward, 1950b, 1953). Reasons are given elsewhere for believing that organisms of the pleuropneumonia group can be distinguished with certainty from bacteria in the L-phase by an adequate examination of their cultural appearances and properties (Edward, 1953).

The serological reactions were tested with antisera prepared in rabbits against several of the strains. The agglutination tests were carried out by the technique previously described (Edward, 1950a), using living suspensions obtained by washing off the organisms from cultures on agar plates with saline. The growth of a pleuropneumonia-like organism is inhibited by incorporating in the culture medium an antiserum prepared against that strain (Edward and Fitzgerald, 1953). An antiserum may be inhibitory even at a dilution of $1: 1,000$, the presence of complement not being required. Since all strains which were agglutinated by a particular antiserum were also inhibited by that antiserum, a convenient test for antigenicity was provided. A suitably diluted suspension of an organism was inoculated on a horse serum agar plate containing antiserum and growth was compared with the growth on a control horse serum agar plate containing normal rabbit serum.

\section{Results of Cultures}

Males.-308 patients were investigated; cultures from the urethra of $\mathbf{3 0 5}$ were examined for pleuropneumonia-like organisms and 53 (17.4 per cent.) were found positive (Table I). Cultures were taken

TABLE I

SUMMARY OF RESULTS OF CULTURES FOR PLEUROPNEUMONIA-LIKE ORGANISMS

\begin{tabular}{|c|c|c|c|c|}
\hline \multirow{2}{*}{ Sex } & \multirow{2}{*}{ Site of Culture } & \multirow{2}{*}{$\begin{array}{l}\text { No. of } \\
\text { Patients }\end{array}$} & \multicolumn{2}{|c|}{$\begin{array}{l}\text { Patients with Positive } \\
\text { Cultures }\end{array}$} \\
\hline & & & No. & Percent. \\
\hline $\begin{array}{l}\text { Male } \\
\text { (308) }\end{array}$ & $\begin{array}{l}\text { Urethra } \\
\text { Rectum and anal canal } \\
\text { Mouth } \\
\text { Joint fluid } \\
\text { Conjunctiva } \\
\text { Keratodermic pustule } \\
\text { Subpreputial sac }\end{array}$ & $\begin{array}{r}305 \\
109 \\
97 \\
4 \\
2 \\
2 \\
1\end{array}$ & $\begin{array}{r}53 \\
6 \\
0 \\
0 \\
0 \\
0 \\
0 \\
1\end{array}$ & $\begin{array}{r}17 \cdot 4 \\
5 \cdot 5 \\
0 \\
- \\
- \\
-\end{array}$ \\
\hline $\begin{array}{c}\text { Female } \\
(\mathbf{1 6 0 )}\end{array}$ & $\begin{array}{l}\text { Cervix and vagina } \\
\text { Rectum and anal canal } \\
\text { Urethra } \\
\text { Mouth } \\
\text { Hydrosalpinx }\end{array}$ & $\begin{array}{r}154 \\
18 \\
6 \\
5 \\
1\end{array}$ & $\begin{array}{r}118 \\
12 \\
2 \\
0 \\
0\end{array}$ & $\begin{array}{r}76 \cdot 6 \\
66 \cdot 6 \\
- \\
-\end{array}$ \\
\hline
\end{tabular}

from the rectum or anal canal from 109 patients, and in six (5.5 per cent.) pleuropneumonia-like organisms were demonstrated. A swab from the preputial sac of one patient gave a positive culture. Pleuropneumonia-like organisms were not isolated from mouth swabs from 97 patients. Cultures of joint fluid from four patients, from the conjunctiva of two patients, and from keratodermic pustules of two patients were also negative.

A diagnosis of non-specific urethritis was made in 140 male patients, and pleuropneumonia-like organisms were isolated from 36 (25.7 per cent.; Table II). There were four ( $11 \cdot 1$ per cent.) positive isolations from 36 patients with acute gonorrhoea without metastatic complications. No genital abnormality was detected in 110 patients, but fourteen (12.7 per cent.) had positive cultures. The frequency of isolation of pleuropneumonia-like organisms from patients with non-specific urethritis was thus about twice that from those with no genital abnormality. In a miscellaneous group (consisting of seven patients with urethritis complicated by arthritis, three with epididymitis, one with prostatitis, two with urethral stricture all without urethritis, two with pyuria, three with lesions of the upper renal tract, three with non-gonococcal proctitis, and one with balanitis) there were three positive isolations, two from patients with proctitis, and the third from the patient with balanitis.

Females.-160 patients were investigated, and 154 cultures from cervix and vagina examined for pleuropneumonia-like organisms ; 118 (76.6 per cent.) were positive (Table I). There were twelve 
(66.6 per cent.) positive cultures from the rectum or anal canal of eighteen patients, and two out of six urethral cultures were positive. Cultures from the mouth of five patients and from one hydrosalpinx were negative.

There were 42 females with gonorrhoea and from $38(90.5$ per cent.) pleuropneumonia-like organisms were isolated, but in four the organisms were isolated from the rectum (Table II). There was therefore a high degree of correlation between the presence of pleuropneumonia-like organisms and gonococcal infection in the female, whereas this was not noted in the male. Pleuropneumonialike organisms were found in 61 (82.4 per cent.) out of 74 women with trichomonas infection; 31 patients in this group also had gonorrhoea. In three patients the organisms were only isolated from the rectum. There was thus also a close association between infection with Trichomonas vaginalis and the presence of pleuropneumonia-like organisms. It is of interest that the cultural requirements of these two organisms are somewhat similar, as both need certain sterols as growth factors (Cailleau, 1937 ; Edward and Fitzgerald, 1951b). Treatment with acetarsol vaginal pessaries had a variable effect in patients with both organisms. Very often both organisms were suppressed by the local treatment, but one or the other or both often reappeared.

TABLE II

ISOLATION OF PLEUROPNEUMONIA-LIKE ORGANISMS

\begin{tabular}{c|l|c|c|c}
\hline \multirow{2}{*}{ Sex } & Diagnosis & $\begin{array}{c}\text { No. of } \\
\text { Patients }\end{array}$ & \multicolumn{2}{|c}{$\begin{array}{c}\text { Patients with Positive } \\
\text { Cultures }\end{array}$} \\
\cline { 3 - 5 } & & No. & Percent. \\
\hline \multirow{3}{*}{ Male } & Non-specific urethritis & 140 & 36 & $25 \cdot 7$ \\
(308) & Acute gonorrhoea & 36 & 4 & $11 \cdot 1$ \\
& No genital abnormality & 110 & 14 & $12 \cdot 7$ \\
& Miscellaneous & 22 & 3 & - \\
\hline \multirow{2}{*}{ Female } & Non-specific cervicitis & 35 & 17 & $48 \cdot 5$ \\
(160) & Trichomonas vaginitis & $74^{*}$ & 61 & $82 \cdot 4$ \\
& Gonorrhoea & $42^{*}$ & 38 & $90 \cdot 5$ \\
& No genital abnormality & 40 & 9 & $22 \cdot 5$ \\
\hline
\end{tabular}

* 31 patients had both gonorrhoea and trichomonas vaginitis.

There were 35 patients with non-specific cervicitis and seventeen ( 48.5 per cent.) gave positive cultures. In forty patients no genital abnormality was detected ; nine (22.5 per cent.) of these had positive cultures, one being in the rectum only. There were three virgins in this group and they all had negative cultures.

\section{Isolation of Organisms from Cases of Non-Specific} Urethritis

Of 140 male patients with non-specific urethritis, 78 were of the abacterial and 62 of the bacterial type. Trichomonas vaginalis was found in the urethral discharge or urine of only four patients.
Abacterial Group.-There were 52 patients with no past history of genital infection; pleuropneumonia-like organisms were isolated from the urethra of fourteen ( 27.0 per cent.) (Table III).

TABLE III

ISOLATION OF PLEUROPNEUMONIA-LIKE ORGANISMS FROM 140 MEN WITH NON-SPECIFIC URETHRITIS

\begin{tabular}{|c|c|c|c|c|}
\hline & \multirow{2}{*}{ Type of Case } & \multirow{2}{*}{$\begin{array}{c}\text { No. of } \\
\text { Patients }\end{array}$} & \multicolumn{2}{|c|}{$\begin{array}{c}\text { Patients with } \\
\text { Positive Cultures }\end{array}$} \\
\hline & & & No. & Percent. \\
\hline \multirow[t]{2}{*}{ Abacterial } & $\begin{array}{l}\text { No past history of genital } \\
\text { infection } \\
\text { Past history of genital } \\
\text { infection }\end{array}$ & $\begin{array}{l}52 \\
26\end{array}$ & $\begin{array}{r}14 \\
2\end{array}$ & $\begin{array}{r}27 \cdot 0 \\
7 \cdot 7\end{array}$ \\
\hline & Total .. & 78 & 16 & $20 \cdot 5$ \\
\hline \multirow[t]{2}{*}{ Bacterial } & $\begin{array}{l}\text { No past history of genital } \\
\text { infection } \\
\text { Past history of genital } \\
\text { infection }\end{array}$ & $\begin{array}{l}36 \\
26\end{array}$ & $\begin{array}{r}11 \\
9\end{array}$ & $\begin{array}{l}30 \cdot 6 \\
34 \cdot 6\end{array}$ \\
\hline & Total .. & 62 & 20 & $32 \cdot 3$ \\
\hline Grand total & total & 140 & 36 & $25 \cdot 7$ \\
\hline
\end{tabular}

The other 26 patients gave a past history of gonorrhoea in twelve cases, non-specific urethritis in eleven cases and acquired syphilis in three cases ; two (7.7 per cent.) had positive cultures.

Bacterial Group.- Of 36 patients with no past history of genital infection, eleven ( 30.6 per cent.) had positive cultures. In the bacterial group of 26 patients, nineteen had a past history of gonorrhoea, five of non-specific urethritis, and two of acquired syphilis ; nine (34.6 per cent.) had positive cultures.

Harkness and Henderson-Begg (1948) isolated pleuropneumonia-like organisms from 14 per cent. of their cases of non-specific urethritis, but cultures were positive in five of ten patients whom they regarded as suffering from acute abacterial urethritis. Harkness (1950) later reported positive isolations from 37 per cent. of 206 cases of abacterial urethritis. We did not isolate pleuropneumonia-like organisms more frequently from men with the abacterial type of infection and with no past history of genital infection than from men in the other groups, but a different method of classification may account for the difference between our findings and those of Harkness. We isolated organisms of the pleuropneumonia group from approximately $26 \mathrm{per}$ cent. of men with non-specific urethritis, and this is in close agreement with the findings of other workers. Beveridge, Campbell, and Lind (1946) reported 20 per cent. of positive isolations, and more recently Melén and Linnross (1952) obtained 18 per cent.

\section{Results of Cultures after Treatment}

In Non-Specific Urethritis. - The effect of therapy was noted in 24 men with non-specific urethritis and 
with positive cultures for pleuropneumonia-like organisms. Streptomycin calcium chloride (1g. intramuscularly) was administered daily for five days. There were fourteen patients whose immediate clinical response to treatment was satisfactory, but cultures for pleuropneumonia-like organisms remained positive. In five patients the clinical response to treatment was satisfactory and the cultures became negative. One patient who relapsed after treatment still had a positive culture, but in four others who relapsed pleuropneumonia-like organisms were not found in the urethra after treatment.

Treatment with aureomycin (aureomycin hydrochloride, $500 \mathrm{mg}$. 8-hrly for 5 days) was given not less than 2 weeks later to twelve patients who had positive cultures in spite of clinical recovery after streptomycin therapy. All patients passed tests for cure 3 months after treatment, but in two of them cultures for pleuropneumonia-like organisms remained persistently positive.

In Consorts.-Pleuropneumonia-like organisms were isolated from the consorts of six men with positive cultures and non-specific urethritis. The women were given the same antibiotic therapy as the male patients and its effect on the persistence of the organisms was noted. After streptomycin in four pairs of consorts, cultures from the male became negative while those in the female remained positive ; one of the males had a clinical relapse (Table IV). In one pair the female became negative and the male remained positive. Both partners in the sixth pair remained positive and were subsequently treated with aureomycin. Cultures in the woman then became negative, but the man remained positive, although he had no clinical relapse. Antibiotic therapy was thus not equally effective in both partners in eliminating the organisms. In vitro tests for sensitivity to the drugs were not carried out to determine whether the strains isolated from the two partners differed in sensitivity.

In Cases of Clinical Relapse.-The course of disease and response to treatment were observed in men 'with non-specific urethritis and no history of genital infection. They were treated with streptomycin and final tests for cure were completed not less than 3 months later. Excluding patients who defaulted before the final tests were complete, there were 44 patients with the abacterial type of infection; twelve of them originally had positive cultures for pleuropneumonia-like organisms and two had a clinical relapse. Among the 32 patients with negative cultures, there were nine who relapsed. In the group with the bacterial type of infection not one of eight patients with positive cultures relapsed, but there were three who relapsed among nineteen patients with negative cultures. Thus clinical relapse occurred rather more frequently among men who originally had negative cultures than among those with positive cultures. The presence of organisms of the pleuropneumonia group in the genital tract did not appear to affect the course of the disease or to increase the risk of complications or relapse. It was also noted that among 19 patients treated for gonorrhoea with penicillin, three had non-gonococcal relapses, although pleuropneumonia-like organisms were not demonstrated in the urethra at any time.

TABLE IV

RESPONSE TO TREATMENT IN PAIRS OF CONSORTS

\begin{tabular}{|c|c|c|c|c|c|c|c|c|}
\hline \multicolumn{3}{|c|}{ Pairs } & Culture & Treatment & Culture & Treatment & Culture & Final Test of Cure \\
\hline \multirow{2}{*}{$1\left\{\begin{array}{l}\text { Male } \\
\text { Female }\end{array}\right.$} & \multirow{2}{*}{$\cdots$} & \multirow{2}{*}{$\begin{array}{l}\cdots \\
\cdots\end{array}$} & \multirow{2}{*}{ Positive } & $\mathbf{S}$ & Negative & - & - & Satisfactory \\
\hline & & & & $\mathbf{S}$ & Positive & $\mathbf{A}$ & Negative & Satisfactory \\
\hline \multirow{2}{*}{$\begin{array}{l}\text { Male } \\
\text { Female }\end{array}$} & \multirow{2}{*}{$\cdots$} & \multirow{2}{*}{$\cdots$} & \multirow{2}{*}{ Positive } & $\mathbf{S}$ & Negative & - & - & Satisfactory \\
\hline & & & & $\mathbf{S}$ & Positive & $\mathbf{A}$ & Negative & Satisfactory \\
\hline \multirow{2}{*}{$\begin{array}{l}\text { Male } \\
\text { Female }\end{array}$} & \multirow{2}{*}{$\cdots$} & \multirow{2}{*}{$\cdots$} & \multirow{2}{*}{ Positive } & $\mathbf{S}$ & Negative, relapse & $\mathbf{A}$ & Negative & Satisfactory \\
\hline & & & & $\mathbf{S}$ & Positive & Defaulted & - & 一 \\
\hline \multirow{2}{*}{$\begin{array}{l}\text { Male } \\
\text { Female }\end{array}$} & \multirow{2}{*}{$\cdots$} & \multirow{2}{*}{$\cdots$} & \multirow{2}{*}{ Positive } & $\mathbf{S}$ & Positive & $\mathbf{A}$ & Negative & Satisfactory \\
\hline & & & & $\mathbf{S}$ & Negative & - & - & Satisfactory \\
\hline \multirow{2}{*}{$\begin{array}{l}\text { Male } \\
\text { Female }\end{array}$} & \multirow{2}{*}{$\cdots$} & \multirow{2}{*}{$\cdots$} & \multirow{2}{*}{ Positive } & $\mathbf{S}$ & Positive & $\mathbf{A}$ & Positive & Satisfactory \\
\hline & & & & $\mathbf{S}$ & Positive & $\mathbf{A}$ & Negative & Satisfactory \\
\hline \multirow{2}{*}{$6\left\{\begin{array}{l}\text { Male } \\
\text { Female }\end{array}\right.$} & \multirow{2}{*}{$\cdots$} & \multirow{2}{*}{$\begin{array}{l}\cdots \\
\cdots\end{array}$} & \multirow{2}{*}{ Positive } & $\mathbf{S}$ & Negative & - & - & Satisfactory \\
\hline & & & & $\mathbf{S}$ & Positive & $\mathbf{A}$ & Negative & Satisfactory \\
\hline
\end{tabular}




\section{Results of Cultures in Other Groups}

In Contacts.-Contact-tracing brought in 69 women who were the contacts of 68 male patients. The results of cultures for pleuropneumonia-like organisms are shown in Table $\mathrm{V}$.

TABLE V

RESULT OF CULTURES FOR PLEUROPNEUMONIA-LIKE ORGANISMS IN 69 FEMALE CONTACTS OF 68 MALE PATIENTS

\begin{tabular}{|c|c|c|c|c|}
\hline \multirow{2}{*}{ Diagnosis } & \multirow{2}{*}{$\begin{array}{c}\text { Result of } \\
\text { Culture } \\
\text { in Male } \\
\text { Patient }\end{array}$} & \multirow{2}{*}{$\begin{array}{l}\text { No. of } \\
\text { Patients }\end{array}$} & \multicolumn{2}{|c|}{$\begin{array}{l}\text { Result of Culture } \\
\text { in Contacts }\end{array}$} \\
\hline & & & Positive & Negative \\
\hline Non-specific urethritis & $\begin{array}{l}\text { Positive } \\
\text { Negative }\end{array}$ & $\begin{array}{l}15 \\
35\end{array}$ & $\begin{array}{l}13 \\
10\end{array}$ & $\begin{array}{r}3 \\
25\end{array}$ \\
\hline Gonorrhoea & Negative & 10 & 6 & 4 \\
\hline No genital abnormality & $\begin{array}{l}\text { Positive } \\
\text { Negative }\end{array}$ & $\begin{array}{l}4 \\
4\end{array}$ & $\begin{array}{l}3 \\
2\end{array}$ & 1 \\
\hline Total & $\begin{array}{l}\text { Positive } \\
\text { Negative }\end{array}$ & $\begin{array}{l}19 \\
49\end{array}$ & $\begin{array}{l}16 \\
18\end{array}$ & $\begin{array}{r}4 \\
31\end{array}$ \\
\hline
\end{tabular}

Cultures were examined from twenty contacts of nineteen men who had positive cultures; sixteen (80 per cent.) of the women were also positive. Each of 49 men with negative cultures brought in one contact and eighteen ( 36.7 per cent.) of the women had positive cultures. Thus positive cultures were more frequent in the contacts of men who were themselves positive than in the contacts of men with negative cultures, but there were many instances where the cultural findings in the two partners differed. Pleuropneumonia-like organisms were not isolated from several female contacts of men with positive cultures, and there were even more men who had negative cultures although the female contact was positive.

In Patients with Arthritis.-Three males and one female suffering from arthritis associated with gonococcal infection and four males with arthritis and non-specific urethritis were observed. Pleuropneumonia-like organisms were demonstrated in the genital tract of the female, but could not be found in the urethra of the five men examined. The joint fluid from four patients was sterile on culture. Pleuropneumonia-like organisms were not isolated from lesions of keratodermia blennorrhagica in two patients or from the conjunctiva of two patients.

From the Anal Canal of Females.-Pleuropneumonia-like organisms were isolated from the rectum and anal canal of twelve out of eighteen women examined. All except two of the women had clinical proctitis. Cultures were examined from both cervix and anal canal from eight patients, and the cervical cultures were positive in addition to the anal cultures in all except one. Nine patients had gonorrhoea and six of these also had trichomonas infection. One of three patients without evidence of gonorrhoea had trichomonas infection. Observation of a larger group of women, including virgins and women with no evidence of genital or rectal infection, would be necessary to determine the frequency with which pleuropneumonia-like organisms inhabit the anal canal in the female. It is not certain whether the organisms reach the anal canal from the vagina or whether the reverse commonly happens. From a few patients swabs were taken both from the anal canal and from the rectum using a proctoscope. The anal swab gave at least as many positives as the rectal swab, and could therefore be used in the examination of a larger group of women.

In a Control Group of Healthy Males.-Organisms of the pleuropneumonia group were isolated from four out of twenty men who on attendance at the clinic showed no evidence of genital infection. In order to extend the findings in healthy males, cultures were made from urethra and anal canal of ninety police candidates who attended for routine serological tests and were found to have no genital abnormality. There were 31 married men and 31 single men who admitted having had sexual intercourse; a further 28 men denied having had sexual intercourse at any time. Pleuropneumonia-like organisms were isolated from the urethra of seven (11.3 per cent.) men with sexual experience ; two also had positive anal cultures. There were three (10.7 per cent.) positive urethral isolations from men who denied intercourse, although it is of course impossible to be sure of the truth of their denial. There were therefore $11 \cdot 1$ per cent. positive isolations from the urethra in this group of apparently healthy men and two $(2 \cdot 3$ per cent.) positive isolations from 88 anal cultures.

The cultures were repeated and confirmed to be positive in seven candidates. In three the organisms were still present in the urethra 3 months later, in another 6 weeks later, and in three others 4 weeks later. Two men gave a past history of non-specific urethritis and one was found at a later examination to have developed signs of a recurrence of this infection. The female contacts of four candidates were examined, but from only one of these were pleuropneumonia-like organisms isolated, although another woman gave a past history of vaginitis treated with pessaries.

\section{Serological Examination of Strains}

Antisera were prepared against five strains ; three had been isolated in the course of this investi- 
gation, one strain in France, and one in America. In cross-agglutination tests one strain, "Campo L", isolated in America, was agglutinated by its own antiserum but not by any of the other antisera, and the antiserum against "Campo L" only agglutinated the homologous organism (Table VI).

TABLE VI

RESULTS OF CROSS-AGGLUTINATION TESTS

\begin{tabular}{|c|c|c|c|c|c|}
\hline \multirow[b]{2}{*}{ Antigen } & \multicolumn{5}{|c|}{ Antisera } \\
\hline & $\underset{\mathbf{H . 2 3}}{\text { Strain }}$ & $\begin{array}{l}\text { Strain } \\
\text { H.26 }\end{array}$ & $\begin{array}{l}\text { Strain } \\
\text { H.50 }\end{array}$ & $\begin{array}{l}\text { Strain } \\
\text { D.419 }\end{array}$ & “ $\underset{\text { Campo }}{\text { Campoin }}$ \\
\hline Strain H.23 & 128 & $<16$ & $<16$ & $<16$ & $<16$ \\
\hline Strain H.26 & 128 & 512 & 256 & 128 & $<16$ \\
\hline Strain H.50 . & 16 & 64 & $\overline{512}$ & 256 & $<16$ \\
\hline$\underset{\text { (France) }}{\text { Strain }}$ D.419 & 32 & 32 & 512 & 1,024 & $<16$ \\
\hline $\begin{array}{l}\text { Strain “ Campo L" } \\
\text { (U.S.A.) }\end{array}$ & $<16$ & $<16$ & $<16$ & $<16$ & 512 \\
\hline
\end{tabular}

Complement-fixation tests and inhibition of growth tests confirmed that "Campo L" differed antigenically from the other four strains. Strain H 23 was not agglutinated by the heterologous antisera, but the $\mathrm{H} 23$ antiserum agglutinated strain $\mathrm{H} 26$ to full titre. Strain H 26 itself was agglutinated by antisera against strains $H 50$ and D 419. The four strains, H 23, H 26, H 50, and D 419, thus share common antigens, although differences exist between them in their antigenic constitution. These four strains will be regarded as belonging to one species of the pleuropneumonia group and will be provisionally called Human Type 1 strains.

The serological reactions of 91 strains isolated in the course of this investigation were tested against

TABLE VII

SEROLOGICAL IDENTIFICATION OF STRAINS ISOLATED

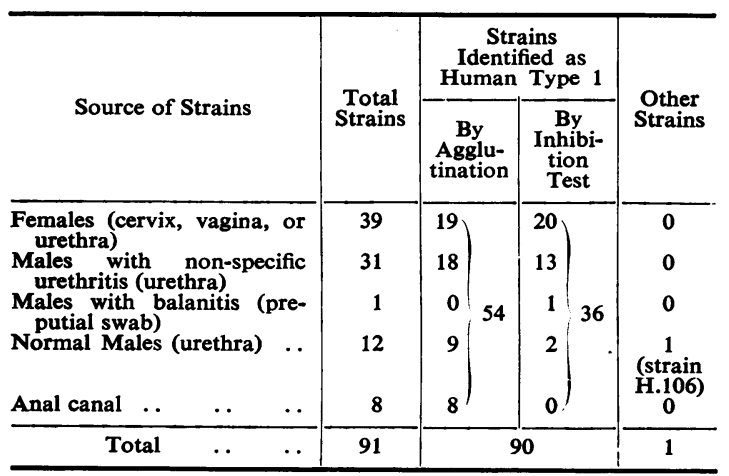

these antisera. Strains from both male and female genital tracts, and from both healthy persons and from persons with genital infection, including males with non-specific urethritis, were included in this series ; there were also eight strains isolated from the anal canal (Table VII). Altogether 54 strains were tested for agglutination, and were agglutinated to a significant titre by at least one of the Type 1 antisera ; the identification of many of these strains as Type 1 was confirmed by the inhibition of growth test. An additional 36 strains, tested only for inhibition of growth, were inhibited by the antiserum against strain $\mathbf{H} \mathbf{5 0}$ (or by that against strain D 419). Thus, all but one of the 91 strains were serologically related to each other and were identified as Type 1. The one exception, strain H 106, will be described later; it had been isolated from a police candidate, who had acquired non-specific urethritis 3 years previously in Malaya, although there was no evidence of disease at the time of examination.

The strains, identified serologically as Type 1, differed from each other in the titres to which they were agglutinated by the four antisera; some strains gave the highest titre with one antiserum and some with another. These differences were not related to the source of the strains. There was no constant difference between strains isolated from patients with infection and strains from apparently healthy persons; strains isolated from the anal canal did not differ from the genital strains.

A number of additional strains which had been isolated by other workers were available for study. Five strains, isolated by Stokes (1953) in London, were identified as Type 1 serologically; one of these strains had been isolated from the blood of a woman with puerperal pyrexia (Table VIII). Two strains, isolated by Durel (1953) in Paris, were also found to be Type 1. Another five strains which had been isolated in the U.S.A. were received from Morton (1953). Two of these were identified as Type 1. A third strain, "Campo L", was seroTABLE VIII

IDENTIFICATION OF ALL STRAINS EXAMINED

\begin{tabular}{l|c|c|c}
\hline $\begin{array}{c}\text { Sources of } \\
\text { Strains }\end{array}$ & $\begin{array}{c}\text { Total No. } \\
\text { Examined }\end{array}$ & \multicolumn{2}{|c}{ Identification } \\
\cline { 3 - 4 } & $\begin{array}{c}\text { Human } \\
\text { Type 1 }\end{array}$ & $\begin{array}{c}\text { Other } \\
\text { Types }\end{array}$ \\
\hline $\begin{array}{c}\text { Isolated by Nicol and } \\
\text { Edward (London) } \\
\text { Received from E. J. Stokes } \\
\text { (London) (including one } \\
\text { strain from blood) }\end{array}$ & 5 & 90 & 1 (strain \\
$\begin{array}{c}\text { Received from P. Durel } \\
\text { (Paris) }\end{array}$ & 2 & 2 & 0 \\
$\begin{array}{c}\text { Received from H. E. E. } \\
\text { Morton (U.S.A.). Ruiter } \\
\text { Received from M. Ruiter } \\
\text { (Holland) }\end{array}$ & 5 & 2 & 3 (Type 2) \\
\hline
\end{tabular}


logically different from the Type 1 strains, and the remaining two strains were serologically similar to it. These last three strains are regarded as belonging to a species of the pleuropneumonia group different from the Type 1 strains and will provisionally be called Human Type 2 strains. Strain "Campo L" was originally isolated by Dienes (1953), who showed that it was serologically similar to each of five other genital strains isolated by him in 1939-40. The five strains, examined by Norman, Saslaw, and Kuhn (1950) and shown to be serologically identical with each other, included strain "Campo L". Thus the strains which had previously been studied serologically were Type 2 strains, all of which had been isolated in America.

Ruiter and Wentholt (1952) isolated pleuropneumonia-like organisms, which appeared to differ from the type usually isolated from the genital tract, from four patients with ulcerative balanitis; they called them " $G$ " strains. One of these strains, examined by us, was serologically different from all the other strains and will be called a Human Type 3 strain.

Biological Properties of Species of the Pleuropneumonia Group of Organisms isolated from the Human Genital Tract

The various species of the pleuropneumonia group of organisms not only differ from each other serologically, but often have distinctive cultural and biochemical properties which assist their identification (Edward, 1950b, 1953) Strains of each of the species isolated from man were therefore examined to determine their properties. The Type 1 strains when grown on horse serum agar did not form the film and spots which are noticeable in cultures of some species of pleuropneumonia-like organisms (Edward, 1950a). The strains grew as well on media enriched with rabbit serum as they did on horse serum agar (Table IX). They grew throughout a semi-solid medium, usually producing a markedly granular growth. They produced little or no haemolysis of horse blood agar and did not ferment glucose.

The Type 2 strains had similar properties, but differed from the Type 1 strains in their pathogenicity for mice. Cultures of each of the three Type 2 strains in semi-solid media (i.e. cultures containing a small proportion of agar) produced local abscesses after subcutaneous inoculation, even though the strains had been through a large number of subcultures over several years. Similar cultures of five Type 1 strains did not affect mice after subcutaneous inoculation.

When the Type 3 strain (" $G$ " strain of Ruiter and Wentholt, 1952, 1953) was grown on horse serum agar, it produced a film and spots similar to those produced by certain other organisms of the pleuropneumonia group. In a semi-solid medium the strain grew best near the bottom where the oxygen tension was lowest ; the growth was smooth. The strain fermented glucose and a number of other carbohydrates. Ruiter and Wentholt (1952) produced local abscesses in mice by injecting this strain into the foot pads, but the strain had lost this property when re-examined in this laboratory. Growth of the strain was improved by adding 20 $\mu \mathrm{g} / \mathrm{ml}$. thymic nucleic acid to the medium.

Strain H 106, the only strain which was not Type 1 to be isolated during the investigation, resembled the Type 3 strain in fermenting the same carbohydrates and in forming a film and spots. It was not, however, agglutinated by an antiserum prepared against the Type 3 strain, and its growth was not inhibited by that antiserum. Since only a single strain was studied, it was not possible to determine whether strain H 106 belonged to a separate species or whether it was a Type 3 strain.

Comparison of the Genital Strains with Strains isolated from the Mouth.--Since organisms of the pleuropneumonia group have been found in the

TABLE IX

PROPERTIES OF SPECIES OF PLEUROPNEUMONIA-LIKE ORGANISMS ISOLATED FROM MAN

\begin{tabular}{|c|c|c|c|c|c|c|c|}
\hline $\begin{array}{c}\text { Species } \\
\text { (or Strain) }\end{array}$ & $\begin{array}{c}\text { Formation } \\
\text { of Film } \\
\text { and Spots }\end{array}$ & $\begin{array}{c}\text { Growth on } \\
\text { Rabbit } \\
\text { Serum Agar }\end{array}$ & $\begin{array}{l}\text { Growth in } \\
\text { Semi-solid } \\
\text { Medium }\end{array}$ & $\begin{array}{l}\text { Granular or } \\
\text { Smooth }\end{array}$ & $\begin{array}{l}\text { Haemolysis } \\
\text { of Horse } \\
\text { Blood Agar }\end{array}$ & $\begin{array}{c}\text { Fermenta- } \\
\text { tion of } \\
\text { Glucose }\end{array}$ & $\begin{array}{l}\text { Pathogenicity } \\
\text { for Mice }\end{array}$ \\
\hline Human Type $1^{*}$ & - & Good & Throughout & Usually granular & $\overline{-}$ & - & None \\
\hline Human Type 2 & - & Good & Throughout & Usually granular & . & - & Abscesses after $\mathrm{s} / \mathrm{c}$ inoc. \\
\hline Human Type $3+t$ & + & Good & At bottom only & Smooth & - & + & Abscesses after $\mathrm{s} / \mathrm{c}$ inoc. \\
\hline Strain H.106† & + & Good & At bottom only & Indefinite & - & + & Not tested \\
\hline Human Type $4+\ddagger$ & + or - & Very good & At bottom only & Smooth & - & - & Not tested \\
\hline
\end{tabular}

* Some strains grew better anaerobically.

$\dagger$ Grew better anaerobically.

$\ddagger$ Growth improved by adding thymic nucleic acid to the medium. 
mouth (Smith and Morton, 1951 ; Dienes and Madoff, 1953), it was necesasry to compare strains from the mouth with genital strains. Saliva, collected from healthy persons immediately after rising in the morning, was cultivated aerobically and anaerobically. All the aerobic cultures were negative, but colonies of pleuropneumonia-like organisms appeared on plates incubated anaerobically, provided that the medium contained $20 \mu \mathrm{g} / \mathrm{ml}$. added thymic nucleic acid. Growth was better if rabbit serum was used for enrichment in place of horse serum. As already noted, pleuropneumonia-like organisms were not isolated from mouth swabs, even though the cultures were incubated anaerobically on media containing thymic nucleic acid. The American workers isolated their strains under aerobic conditions on media to which nucleic acid had not been added (Smith and Morton, 1951; Dienes and Madoff, 1953). It is not clear why we obtained different results. No serological or other comparison has yet been made between our strains and the American strains.

Five strains isolated from saliva were examined. Three of them formed a film and spots on horse serum agar ; the other two did not. All the strains grew best near the bottom of semi-solid media producing a smooth growth. They did not ferment glucose. An antiserum, prepared in a rabbit against one strain, inhibited growth of the homologous strain and of each of the other strains. Agglutination tests were unsatisfactory because of the poor agglutinability of some of the strains. The strains from saliva were antigenically different from the genital strains, there being no cross-reactions with genital types in agglutination and inhibition of growth tests. These strains will therefore be provisionally called Human Type 4 .

Effect of Anaerobiosis and of an Atmosphere of $\mathbf{1 0}$ per cent. $\mathrm{CO}_{2}$ upon Growth.-It has been reported that some strains of pleuropneumonia-like organisms could be isolated from the genital tract and genital organs only if anaerobic methods of cultivation were employed (Dienes and others, 1948 ; Ruiter and Wentholt, 1952). On a number of occasions in this investigation, colonies of pleuropneumonia-like organisms appeared on plates incubated anaerobically, whereas corresponding plates incubated aerobically were negative. Unfortunately duplicate aerobic and anaerobic cultivation was not carried out throughout the investigation, but in a series of 35 urethral cultures from cases of non-specific urethritis, the use of both methods of cultivation did not give a higher proportion of positive isolations than in the whole series. There was therefore no evidence that, if anaerobic cultivation had been used throughout, there would have been a significantly greater number of positive isolations.

The need of certain Type 1 strains for anaerobiosis appears to depend upon conditions in the medium, particularly upon $p \mathrm{H}$. When a urethral sample containing large numbers of Type 1 pleuropneumonia-like organisms was inoculated on media at $p \mathrm{H} \mathrm{8,} \mathrm{there} \mathrm{was} \mathrm{growth} \mathrm{on} \mathrm{a} \mathrm{plate} \mathrm{incubated} \mathrm{anaero-}$ bically and on a plate incubated in an atmosphere of 10 per cent. $\mathrm{CO}_{2}$, whereas there was no growth on a plate incubated aerobically (Table $X$ ). The same sample was inoculated on to media of similar constitution adjusted to $p \mathrm{H}$ values of $7,6.5$, and 6 , and the cultures were incubated aerobically. There was growth on the media at $p \mathrm{H} 6.5$ and 6 , but not on the medium at $p \mathrm{H} \mathrm{7.} \mathrm{Thus} \mathrm{this} \mathrm{strain} \mathrm{was} \mathrm{capable} \mathrm{of}$ growing aerobically in the particular culture medium provided the conditions were acid, whereas in a more alkaline medium anaerobiosis was necessary.

TABle $X$

EFFECT OF ANAEROBIOSIS AND OF $p H$ ON GROWTH

\begin{tabular}{c|c|c|c|c|c|c}
\hline \multirow{2}{*}{ Strain } & \multicolumn{2}{|c|}{ Medium at $p \mathrm{H} \mathrm{8}$} & $p \mathrm{H} \mathrm{7}$ & $p \mathrm{H} 6.5$ & $p \mathrm{H} 6$ \\
\cline { 2 - 6 } & $\begin{array}{c}\text { Anaero- } \\
\text { biosis }\end{array}$ & $\begin{array}{c}10 \text { per } \\
\text { cent. } \\
\text { CO, }\end{array}$ & $\begin{array}{c}\text { Aero- } \\
\text { biosis }\end{array}$ & $\begin{array}{c}\text { Aero- } \\
\text { biosis }\end{array}$ & $\begin{array}{c}\text { Aero- } \\
\text { biosis }\end{array}$ & $\begin{array}{c}\text { Aero- } \\
\text { biosis }\end{array}$ \\
\hline $\begin{array}{c}\text { Human Type 1 } \\
\text { (Primary iso- }\end{array}$ & + & + & - & - & + & + \\
$\begin{array}{c}\text { lation) } \\
\text { Human Type 3 }\end{array}$ & + & \pm & - & Tr. & \pm & \pm \\
Human Type 4 & + & Tr. & Tr. & Tr. & Tr. & Tr. \\
\hline
\end{tabular}

The Type 3 strain grew well on the medium at $p \mathrm{H} 8$ incubated anaerobically, there being no growth on the same medium incubated aerobically. Growth was only moderately good on the same medium incubated in an atmosphere of 10 per cent. $\mathrm{CO}_{2}$. There was also moderately good growth on media adjusted to $p \mathrm{H} 6.5$ and 6 and incubated aerobically. Reducing the $p \mathrm{H}$ of the medium did not permit satisfactory growth under aerobic conditions of a Type 4 strain which had been isolated from saliva by anaerobic cultivation.

It is concluded that cultures from the human genital tract should be incubated both aerobically and anaerobically to ensure growth of all strains of pleuropneumonia-like organisms. Cultivation in an atmosphere of 10 per cent. $\mathrm{CO}_{2}$ could be used as an alternative to anaerobiosis, although Morton, Smith, and Leberman (1951) noted that an atmosphere of $\mathrm{CO}_{2}$ suppressed growth of some strains on their media.

\section{Discussion}

Organisms of the pleuropneumonia group were isolated from 26 per cent. of cases of non-specific 
urethritis. This percentage of positive isolations was at least as high as the percentages reported by other workers. Although the pleuropneumonia-like organisms which were isolated grew well and easily on the media employed, it is possible that sometimes cultures failed to reveal pleuropneumonialike organisms when they were present in the urethra. It is however unlikely that the cultural methods failed in 75 per cent. of patients. In threequarters of all cases of non-specific urethritis, therefore, organisms of the pleuropneumonia group were not found and could not be incriminated as the cause of the infection. Clinically no difference was noted between the cases with positive cultures and those with negative cultures. The course of the disease and the response to treatment did not appear to be affected by the cultural findings. It would thus appear that a cause for non-specific urethritis must be sought other than pleuropneumonia-like organisms of the types already isolated.

Pleuropneumonia-like organisms, which had the same serological and biological properties as strains isolated from men with non-specific urethritis, were isolated from 11 per cent. of a group of police candidates, who had no evidence of genital infection. These organisms were regarded as belonging to one species of the pleuropneumonia group and were called Human Type 1 strains. All except one of 91 strains isolated in the course of the investigation were identified as Type 1 . The presence in the urethra of organisms of Type 1 did not appear to increase the liability of patients with non-specific urethritis to complications. Relapses occurred in patients with negative cultures. Ruiter and Wentholt (1953) investigated the pathogenicity of a strain of pleuropneumonia-like organism isolated from a patient with non-specific urethritis by inoculating a culture into the urethra of two male volunteers. The inoculation was without effect. If the pathogenicity of Type 1 pleuropneumonia-like organisms is considered in the light of these separate findings, it would seem probable that the organisms do not play a significant role in non-specific urethritis, although the possibility cannot be excluded that they may produce suppurative lesions in the genital tract under certain circumstances.

Thus the evidence suggests that organisms of Type 1 are commensals. Both in males and females the organisms are found more frequently where there is evidence of inflammation. Possibly persistence in the genital tract is favoured by inflammatory conditions, but the organisms persisted in the apparently healthy urethra of three males for at least 3 months. The organisms probably reach the male urethra during sexual intercourse, at least in the majority of instances, but a non-venereal method of spread may possibly occur in the female. Type 1 organisms were sometimes found in the anal canal. In most instances cultures from both anal canal and genital tract were positive so that it is impossible to establish where the organisms resided first, but spread from the anus to the vagina would seem a possibility.

Several species of the pleuropneumonia group of organisms have a tendency to localize in joints, and so particular attention has been paid to pleuropneumonia-like organisms in considering the aetiology of arthritis, when it occurs as a complication of urethritis. Pleuropneumonia-like organisms have been isolated directly from joint fluids on a few occasions (Dienes and others, 1948; Kuzell and Mankle, 1950), but in many other attempts the cultures have been negative. We failed to isolate these organisms from the urethral tract, joint fluid, and other lesions of several cases of gonococcal and non-specific urethritis. It is difficult to assess the significance of the few positive isolations made from joint fluid, because pleuropneumonia-like organisms are known to be capable of lying latent inside the body, for instance in the brains of healthy mice (Sabin, 1941). All the successful isolations from joint fluid were made in the U.S.A. It is to be noted that strains of a different species of the pleuropneumonia group have been isolated in America from the genital tract. The Type 2 strains. were pathogenic for mice, but pathogenicity for mice does not necessarily indicate pathogenicity for man. Further work will be required to determine the significance of the Type 2 strains.

\section{Summary}

Organisms of the pleuropneumonia group were isolated from the urethra of 26 per cent. of 140 men with non-specific urethritis. Relapses occurred during treatment in men with negative cultures. Similar organisms were found in the urethra of 11 per cent. of ninety men with no genital abnormality, there being three positive isolations from men who denied sexual intercourse. Cultures from the cervix and vagina of 154 women showed that 77 per cent. were positive, the proportion positive being even greater in women with gonorrhoea or trichomonas infection. Pleuropneumonia-like organisms were also isolated from the anal canal of males and females, both in association with proctitis and in the absence of signs of infection.

All except one of 91 strains were shown by their serological and biological properties to belong to one species of the pleuropneumonia group of 
organisms ; they were called Human Type 1 strains. Strains from healthy persons did not differ from strains isolated from patients with infection; genital strains were similar to anal strains. A few strains isolated in America from the genital tract, one strain isolated in Holland from an ulcerated glans penis, and strains isolated from saliva, belonged to three other different species of the pleuropneumonia group.

Type 1 pleuropneumonia-like organisms cannot be incriminated in the aetiology of 75 per cent. of cases of non-specific urethritis, and another cause for this infection must therefore be sought. The pleuropneumonia-like organisms appear to be commensals and no evidence was obtained that they played a significant role in genital infection, although the possibility that they may produce suppurative lesions under certain circumstances cannot be excluded.

Our thanks are due to Mr. A. J. King, Senior Physician, and to other members of the medical and nursing staff of the Whitechapel Clinic of the London Hospital, and to the medical and nursing staff of the Special Treatment Centre of St. Bartholomew's Hospital, for their help in collecting the clinical material, and to Dr. D. R. Crabb for allowing us to take tests from Police candidates. We also wish to thank Prof. $M$. Ruiter, Prof. H. E. Morton, Dr. L. Dienes, and Dr. E. J. Stokes for supplying us with cultures.

\section{REFERENCES}

Beveridge, W. I. B., Campbell, A. D., and Lind, P. E. (1946). Med. J. Aust., 1, 179.

Cailleau, R. (1937). Ann. Inst. Pasteur, 59, 293.

Dienes, L. (1940). Proc. Soc. exp. Biol., N.Y., 44, 468.

(1953). Personal communication.

—, and Edsall, G. (1937). Proc. Soc. exp. Biol., N.Y., 36, 740.

- and Smith, W. E. (1942). Ibid., 50, 99.

—_, and Madoff, S. (1953). Ibid., 82, 36.

—, Ropes, M. W., Smith, W. E., Madoff, S., and Bauer, W. (1948). New Engl. J. Med., 238, 509, 563.

Durel, P. (1953). Personal communication.

Edward, D. G. ff. (1947). J. gen. Microbiol., 1, 238.

(1950a). Ibid., 4, 4.

(1950b). Ibid., 4, 311.

- (1952). British Journal of Venereal Diseases, 28, 89.

(1953). J. gen. Microbiol., 8, (In the press).

—, and Fitzgerald, W. A. (1951a). Ibid., 5, 566.

$\longrightarrow, \longrightarrow$ (1951b). Ibid., 5, 576.

—- (1953). J. Path. Bact., 65, (In the press).

Harkness, A. H. (1950). " Non-gonococcal Urethritis". Livingstone, Edinburgh.

Diseases, 24, 50.

Kuzell, W. C., and Mankle, E. A. (1950). Proc. Soc. exp. Biol., N.Y., 74, 677.

Melén, B., and Linnross, B. (1952). Acta derm. venereol., Stockh., 32, 77.

—, and Odeblad, E. (1952). Ibid., 32, 74.

Morton, H. E. (1953). Personal communication.

, Smith, P. F., and Leberman, P. R. (1951). Amer. J. Syph., 35, 14.

Norman, M. C., Saslaw, S., and Kuhn, L. R. (1950). Proc. Soc. exp. Biol., N.Y., 75, 718.

Randall, J. H., Stein, R. J., and Ayres, J. C. (1950). Amer. J. Obstet. Gynec., 59, 404.

Ruiter, M., and Wentholt, H. M. M. (1952). J. invest. Dermat., $18,313$.

-_, (1953). Acta Derm. venereol., Stockh., 33, 130.

Sabin, A. B. (1941). Bact. Rev., 5, 1.

Smith, P. F., and Morton, H. E. (1951). Science, 113, 623.

Stokes, E. J. (1953). Personal communication. 